\title{
Wellbeing and Work: Social Inclusion of Vulnerable Groups in Northern Spain
}

\author{
Oscar Fernández
}

\section{Introduction}

The European Union considers employment to be the best protection against social exclusion. All the policies and actions that are on offer from the various bodies and organizations in this area are directed towards achieving this objective and concentrate on the people involved obtaining employment. Nonetheless, the great heterogeneity noticeable in these processes shows the necessity of providing responses, actions and programmes that are differentiated and specific. With this requirement, interventions must address in an integrated and open way the needs arising in given contexts. The work being described here was carried out in the urban district of Ponferrada in the Province of Leon in Spain through a case study on the employability of certain groups at risk of exclusion. This is the first stage towards a comparative study we are carrying out in southern European countries including Portugal and Italy.

The study had the participation of groups that are users of the services of the Social Action department of the municipal authority. This means that it was used the database of the municipal social services, offered by them, because they were the main interested in solve the problem of their unemployment users. The groups we work with were similar to those countries described before. Among them are women at risk, who were the majority of people, the disabled, immigrants, the population of drug addicts and former addicts, and other groups such as the homeless or ethnic minorities.

A special case in these ethnic minorities is the Romany community. The marginalization of the Romany community in Spain, as elsewhere in the world, has its roots in a centuries-old history of ethnic segregation. In response, the Romany community has come to feel intimidated and rejected. This has led to the establishment of communities on the outskirts of cities, generally with very poor living standards. The historical past still has a significant impact on the manner in which mainstream society tends to relate to the Romany community. All statistical indi- 
cators show this community to be the most widely rejected group in European society.

As it will be showed, the majority of participants were women aged between 30 and 50. This offers the first clues as to the sort of difficulties for work insertion faced by this age range among the different groups.

A qualitative methodological design was used. One feature investigated was the various factors that make people belonging to these groups liable to exclusion. These factors relate primarily to the personal, family, educational, training, social, cultural, and life experience circumstances of the different individuals involved. Another feature was the position adopted by employers with regard to such groups. On the basis of an analysis of the data, a range of tools, strategies and competencies was outlined for consideration so as to achieve their social inclusion.

Awareness of the real situation of the people in certain groups at risk of exclusion from society and the world of work was the fundamental criterion guiding this research. On the basis of this primary criterion, the objectives proposed for the investigation were the following:

1. To identify and analyse the factors restricting the employability of vulnerable groups.

2. To discover and define the competencies for employability of such groups, at various levels of professional qualification.

3. To construct tools for inclusion and for evaluating employability, taking into consideration competencies and risk factors.

\section{Theoretical Framework}

When vulnerable groups are mentioned, two fairly closely related concepts come into play: poverty and social exclusion. Generally research into social exclusion contributes to studies on poverty, since these have been increasingly taking into account social, rather than purely monetary considerations.

In social research, as noted by Hilary Silver ${ }^{1}$, work at present generally concentrates on the indicators that allow social exclusion to be measured. For example, the indicators proposed by Barnes ${ }^{2}$ covered seven dimensions of social exclusion: financial situation, ownership of consumer durables, quality and habitability of housing, perception of the neighbourhood, personal social relationships, physical

1 Silver, Hil "The process of social exclusion: the dynamics of an evolving concept", Chronic Poverty Research Centre, Working Paper, 95. (London, 2007).

2 Barnes, M. Social Exclusion in Great Britain. An Empirical Investigation and Comparison with the EU. (Aldershot, 2005). 
health and psychological well-being. In earlier work, Barnes et al. ${ }^{3}$ measured exclusion as a multidimensional disadvantage in the areas of housing, health, education, social relationships and participation.

Using the British Household Panel Survey, Burchardt, Le Grand and Piachaud ${ }^{4}$ worked with four inter-related systems of indicators of participation in normal social activities: (i) consumption (less than half the average household income or revenues) and savings; (ii) production (those who are economically active but not linked to any valued social activity); (iii) political linkages or commitments (those who do not vote or belong to any political organization); and, of most importance for the present purpose, (iv) social interaction (absence of anyone to offer support, such as listening, comforting, or helping in a crisis, or of somebody with whom to relax and have a good time, or someone who really appreciates them).

The Rowntree Foundation sponsored a team of researchers in Bristol ${ }^{5}$ to conduct a new survey of poverty and social exclusion. They utilized secondary data and information to study four themes relating to social exclusion: (i) poverty in terms of income and lack of material goods; (ii) exclusion from the labour market; (iii) exclusion from public services; and (iv) exclusion from social relationships. Four aspects of this latter topic, social relationships, received particular attention. Firstly, there were indicators of participation in common social activities. Respondents indicated if they considered an activity essential, that is if they were really involved in it, and if not, why they avoided it. In respect of certain essential social activities, sizable minorities were found not to have even one free afternoon a fortnight, not to eat out even once a month, or not to have even one week's holiday away from home, or had no hobby or pastime, or no group of friends with whom to go out for a meal or a drink. Secondly, indicators of social isolation and solitary life included marital status and family composition. Thirdly, isolation and non-participation implied the lack of social aid, both emotional and material. Fourthly, decoupling from any civic or electoral matters was the norm, rather than any formal linkage or even any actual participation in public affairs. One major innovation of this work is that it examined specifically social aspects of exclusion.

German studies have used other dimensions of exclusion. For example, Kronauer listed the roots of exclusion from the world of work: financial, cultural, spatial, social and institutional as quoted by Littlewood and Herkommer ${ }^{6}$. On other hand,

3 Barnes, M., Heady, C., Middleton, S., Millar, J., Papadopoulos, F., Room, G., and Tsakloglou, P. Poverty and Social Exclusion in Europe. (Cheltenham, 2002).

4 Burchardt, T., Le Grand, J. and Piachaud, D. "Degrees of exclusion: developing a dynamic, multidimensional measure”, in Hills, J. Le Grand, J. and Piachaud, D. (eds), Understanding Social Exclusion. (Oxford, 2002).

5 Gordon, D., et al., Poverty and Social Exclusion in Britain. (York, 2000).

6 Littlewood, P. and Herkommer, S. "Identifying social exclusion: some problems of meaning", in Littlewood, P. (ed.), Social Exclusion in Europe: Problems and Paradigms. (Aldershot, 1999), pp. 1-22. 
Petra Böhnke ${ }^{7}$ used Eurobarometer surveys to measure social exclusion in subjective terms, creating an index of belonging that was related to social support and family ties, as also to confidence in institutions. She also utilized the German Welfare Survey of 1998, to find a relationship between distributional or material exclusion and relational or participatory exclusion. To sum up, researchers have drawn up a varied panorama of the dimensions of social exclusion, in order then to attempt to correlate them. However, these studies have largely been based on transversally sectioned micro-data.

In December 2000, at Nice, the Council of the E.U. decided that the struggle against social exclusion was to be given a legal basis, and set about co-ordinating the social dimension of E.U. strategy. Every two years, starting in June 2001, member states were to draw up plans for national actions aimed at social inclusion, progressing towards agreed goals for a range of social indicators, which were to take into account national variability. Between 2001 and 2003, A. B. Atkinson and others $^{8}$ worked out strategies based on the distribution of income, access to the labour market (measured in terms of levels of employment and unemployment, and of unemployment as a characteristic of a family), the functioning of the education system (measured in terms of school drop-out rates) and of access to health care (measured by life expectancy). The Commission's attempt to consolidate the "social dimension" of the Lisbon Strategy for growth and employment, and its efforts to reform social inclusion affected first pensions, then health and medical care. The Commission's moves to stimulate this process also involved a reduction in the number of strategy reports to a frequency of one every three years from 2006 onwards. The indicators for inclusion drawn up by the E.U. must be viewed critically, since in general they refer to the world of work rather than to citizenship or political participation or to many other aspects that may affect immigrants. For example, they have no word to say about re-uniting families, ensuring that people feel safe or similar matters.

Recognizing the challenges of social cohesion and the peaceful incorporation of newcomers through a process of mutual acceptance and tolerance, the British Council of Brussels Foreign Policy Centre and Migration Policy Group began developing the "European Civic Citizenship and Inclusion Index". This was intended to indicate the degree to which immigrants have rights and obligations comparable to those of E.U. citizens. The index was based on nearly one hundred indicators from five political areas, grouped progressively as a progression towards complete citizenship, and thus incorporated a dynamic logic. The index accepted that the process of inclusion of immigrants requires: (i) inclusion in the labour

7 Böhnke, P. Am Rande der Gesellschaft: Risiken sozialer Ausgrenzung. (Opladen, 2006).

8 Atkinson, A. B., Cantillon, B., Marlier, E. and Nolan, B. Taking forward the EU social inclusion process. (Luxembourg, 2005),

Hhttp://www.ceps.lu/eu2005 lu/inclusion/report/final report.pdf 
market, (ii) re-uniting of families, (iii) long-term residence rights, (iv) naturalization, and (vi) anti-discriminatory measures. The first annual report provided data from 2003 for each country, and revealed that, as might be expected in a context of dependency and exclusion, countries were implementing their own commitments to inclusion in very different ways, although tending to align themselves on the five areas.

In Spain, the Observatory of Processes of Exclusion and Social Incorporation created by the SARTU Federation in 2001 is the leader in the creation of information tools putting scientific research at the service of individuals and of social intervention. Among the novel features it incorporates is an attempt to reconcile social bodies, institutions and economic agents in order to handle these questions. For this purpose its work has concentrated on the construction of social indicators of exclusion and incorporation into society, and on the factors affecting these, by means of carrying out studies and creating specific working parties. To achieve this, the Observatory is organized around three axes or areas of action:

1. Study of the processes of incorporation of people who are excluded or at risk of exclusion, viewed longitudinally.

2. Study of professional practices aimed at the social incorporation of groups that are in a situation of exclusion or at risk of being excluded.

3. Exchange of information good practice norms between the various social bodies and agents involved in the processes of social incorporation of groups suffering from or at risk of exclusion.

On the basis of the work undertaken by the teams participating in this observatory, it can be deduced that, unlike poverty and marginalization, the phenomenon of exclusion is not related solely to financial weakness, which could be dealt with by policies for minimum incomes, but rather to the weakness of social linkages. This has also been pointed out by Fitoussi ${ }^{9}$ and Castel $^{10}$. Situations of exclusion, in the most extreme case, may involve a complete breaking of relationships and the isolation of people, leading to a deficit in social cohesion. This phenomenon co-exists alongside a context of economic growth, which makes it even harder for those who are in a situation of exclusion or at risk of being excluded to face up to the problem, or to bear it.

From a sociological point of view, it should be emphasized that exclusion is not limited to any single social class. On the contrary, one characteristic of advanced technological societies is the risk of destabilization of the stable, triggered by processes of rapid downward mobility.

9 Fitoussi, J. and P. Rosanvallon, La nueva era de las desigualdades, ed. Manantial, (Buenos Aires, 1998).

10 Castel, R., Las metamorfosis de la cuestión social. (Buenos Aires, 1997). 
From this perspective, the process of social incorporation may be understood in operational terms as the process undertaken by people, whether at their own initiative or at the suggestion of systems for social protection, with the intention of achieving a change in social position such as to allow them to move from a situation or risk of exclusion towards circumstances of integration. Such a process of social incorporation affects one or more areas of life related to employment, housing, income, training, education, legal status; family situation, health, social participation and personal development.

$\mathrm{Gil}^{11}$ notes the particular features arising from speaking of "social and work" insertion, as opposed to "work" or "social" insertion on its own. This leads to a conglomerate of different policies, measures and actions that sometimes are of varying types with differing approaches, and involve different players (public and/or private). Nonetheless, all these actors should be brought together by the purpose of ensuring that unemployed individuals can get a job and be able to live a life as similar as possible to those of their fellow citizens. Among the factors relating to the individual, mention can be made of determinants such as sex, age, the social surroundings in which individuals find themselves, training, experience, capacity to learn, attitudes towards insertion, vocational maturity or preparedness for seeking employment, amongst others.

In the views expressed in the work cited, what defines insertion actions is the profile of users or subjects of them, and more specifically the needs that characterize the latter. These, according to Gil, shape a given life scenario, in which the presence of deficiencies or unfulfilled potentials relating to work, training, education, finances and so forth builds up a complex web of threatened or actual social exclusion. This is affected or acted upon by social and work insertion actions, and implies a lack of integration into community and society.

One note with respect to the migrant population in particular, as the largest group requiring insertion, is that the IOE Group ${ }^{12}$ investigated the characteristics of foreign immigration and its consequences for the shape of Spanish society. It is an interesting approach that provides a cross-section of the world field in which migrations take place. This is because it leaves to one side the circumstances of their societies of origin and their inclusion into the world scene, as also the increasing links that migrants are establishing between various countries, acting as they sometimes do as authentic transnational communities.

11 Gil, M.A., "Empresas de inserción: contexto, orígenes y situación”. Herramientas, (2003) 69, pp. 34-41.

12 Colectivo IOÉ, "Inmigrantes extranjeros en España ¿Reconfigurando la sociedad?", Panorama Social, (2005), 1, pp. 32-47. See also: Colectivo IOÉ, "Barómetro Social de España: nuevos indicadores sobre la evolución del país" en Papeles de relaciones ecosociales y cambio global, CIP-FUHEM, 101 (2008), pp. 165-185. 


\section{Content of the Study}

The study concentrated principally upon the identification of the factors making employability hard to achieve, that is to say, the social and work inclusion of the following groups:

- Women at risk,

- The disabled,

- Immigrants,

- Ethnic minorities,

- Population of drug addicts and former drug addicts, and

- Other excluded groups or those at risk of exclusion.

In the case of women, a distinction may be made in accordance with whether they were single mothers; separated women, sometimes with family responsibilities, who were coming into the world of formal work for the first time; abused women, victims of domestic violence; and women aged over 45. In some instances, more than one of these profiles fitted a single person. These were the groups directly involved in the work.

We would like to say something about the position of Romany women. Young Romany women are especially isolated, since they both belong to marginal ethnic group and they are women. Young girls between the ages of 9 and 16 are expected to give up the childhood to take on mature family responsibilities. Boys, just because they are boys, enjoy a series of privileges that start at an early age. With the responsibility girls have in the family it is more likely they will miss school or end their school careers completely. Because they are women they have to do the household chores and take care of younger children. Girls are the pillar of family organization, yet this leads to truancy and the perpetuation of illiteracy. Moreover, Romany culture does not consider a girl's education necessary. Even mothers do not regard mainstream non-Romany education as something important for their daughters' future.

On the basis of reflections obtained from the previous section, an attempt was made to look closely at specifically social aspects. For this reason, attention was paid to features governing the theme under consideration, but from the perspective of the family and of the household, Hence, fieldwork took into account a study of the position of women within the family; division of labour between the sexes for family chores; power relations within the household: access to resources, decision taking; transmission of the values typical of the social environment of the family; family, school and training; the creation and articulation of networks for co-operation and help within and outside the family; access to information and the different ways it is used; the situation of the young; personal, social and identity conflicts; and the like. 


\section{Development of Methodology}

The core methodological approach for the undertaking of this study has its roots in Socio-cultural Anthropology. In this way, the field work technique was an ethnographical method, so that it concentrated on a qualitative investigation. The research began with the drawing up of a survey script intended to cover the stated objectives, as well as to permit identification of the profile of users of the social services provided by the local authorities in Ponferrada.

Initially, 290 users of social services took part, being identified from a database provided by the services themselves. Later an attempt was made to get broader and more intensive participation on a voluntary basis, so that the size of the sample shrank ${ }^{13}$. Little by little, joint sessions were held, attendance these also being voluntary, which allowed common points in the same problem area for differing groups to be highlighted.

In parallel a questionnaire was drawn up, intended for entrepreneurs, institutions, trade unions, non-government organizations and other bodies, with an eye to learning the requirements of the labour market in respect of sectors, training, skills, abilities and other work competences in relation to the groups at risk of exclusion. After this information had been gathered, it was interpreted in such a way as to permit analysis of the causes of the social and work exclusion of these groups, and also to offer solutions for including them. The data obtained from the first part of the semi-structured questionnaire were subjected to a statistical treatment, so as to evaluate the representativeness of the sample. They are displayed in graphs that indicate the real data. Co-ordination with the Social Action department of the $\mathrm{Mu}$ nicipality of Ponferrada was continuous and fluid. This was because in principle it was a question of resolving doubts that had arisen within this department, the work being carried out at times when one or the other of the two sides requested.

Through the field work, it was intended to analyse and assess an employability or "placeability" index. It was desirable to learn about the following:
a. Value and worth set on employment.
b. Attribution of unemployment.
c. Availability for employment.
d. Self-image, personal and occupational.
e. Style of seeking employment.
f. Occupational maturity.
g. Demonstrated job-seeking skills.
h. Social and family support
i. Need for insertion.

13 The author would like to express thanks at this point to all those participating in the study, as also to the people and institutions that encouraged and facilitated it. 


\section{Field Work with Various Groups}

\section{Sample and Profile of the Population under Study}

In undertaking the work, a database provided by the Social Action department of the Municipality of Ponferrada was used, this listing users suitable as participants in the study. This database contained 290 users, as noted above. With the data gathered during field work, various graphs have been produced here to show user profiles. All these graphs show actual totals for the population under study, not percentages.

With respect to the profiles of the users of social services who were involved in the work, as shown by Graph 1, they were mostly women. The majority were women aged between 30 and 50, with the numbers of women aged between 20 and 30 and of women over 50 being roughly the same. The proportion of men in the various age groups was similar, but they were fewer in number. As may be observed, the majority of participants were aged between 30 and 50 . This offers the first clues as to the sort of difficulties for work insertion faced by this age range among the different groups.

Figure 1. Study Population by Age and Sex.

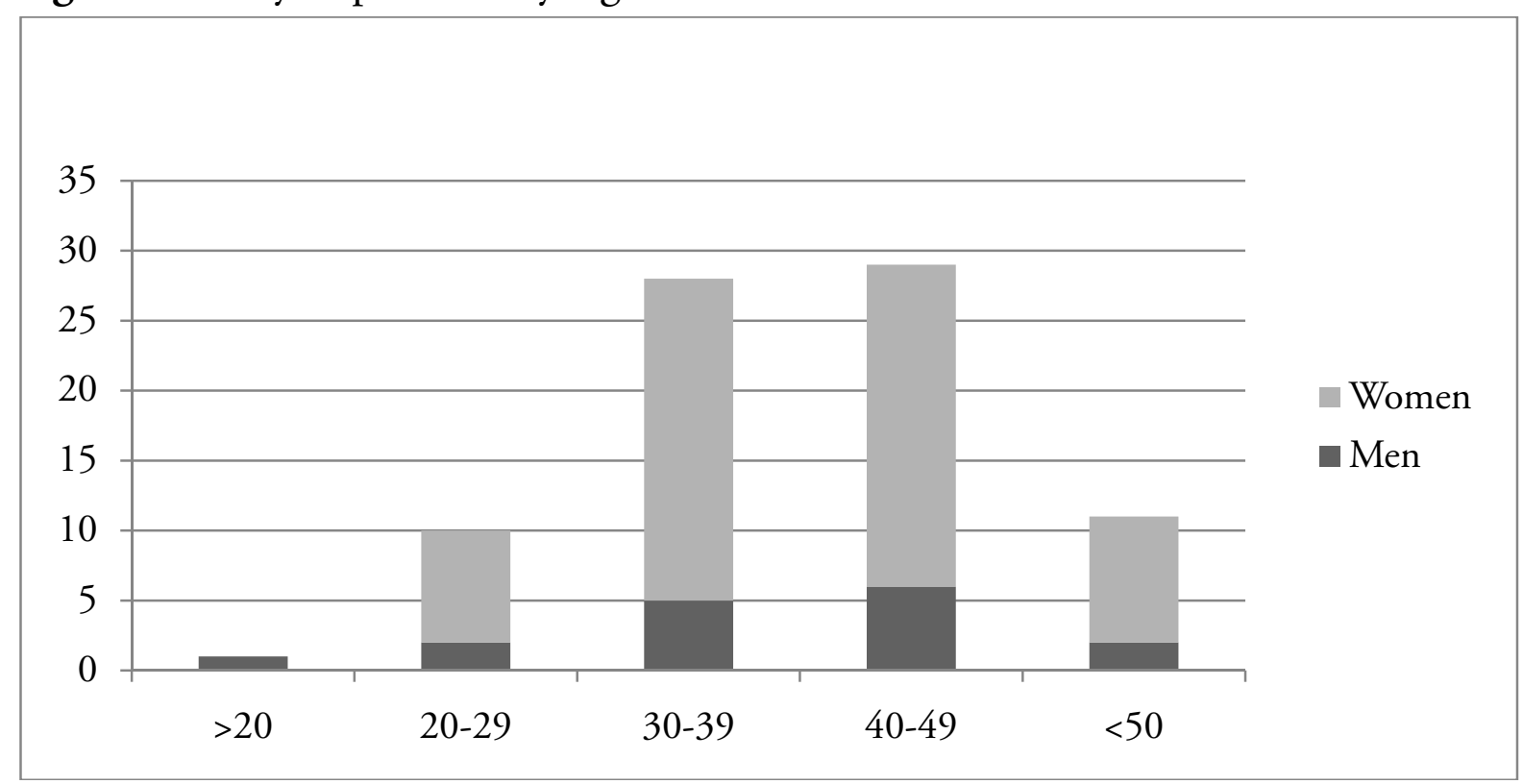

Source: Own elaboration.

With respect to the marital status of those participating in the study, there is a difference by age group. As can be seen from Graph 2, the women taking part in the study were mostly separated or divorced individuals aged between 30 and 50, these constituting virtually half of all the women involved. A further two sectors of 
some importance were single women aged between 20 and 29 and married women between 30 and 39 years old.

With regard to men, married men aged between 30 and 39 were prominent, after whom came separated, single and married men from the age range 40 to 49 years old. The graph in question shows the total of those actually participating in the study divided according to sex, marital status and age group. As may be observed, there was a preponderance of separated or divorced individuals who were in the age range 30 to 50 years old.

Figure 2. Marital Status by Age and Sex.

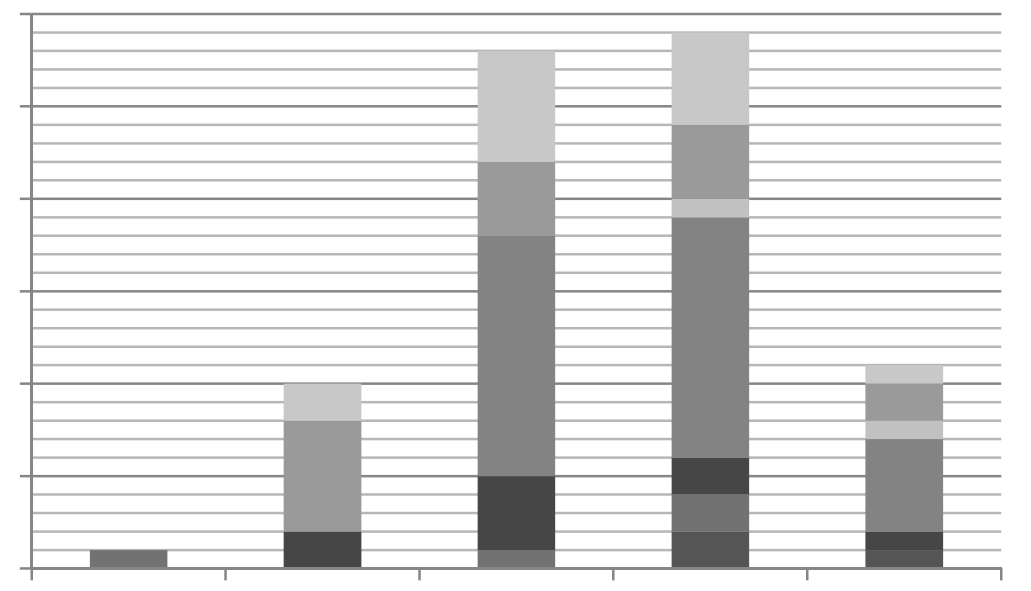

Married Women

- Spinsters

- Widows

- Separated or Divorced Women

- Married Men

- Bachelors

Source: Own elaboration.

With regard to education, the largest group among women was those with a basic level: primary and the compulsory part of secondary studies only. There was also a large group of women aged between 40 and 50 who had studied at secondary level up to an academic or vocational school-leaving certificate standard. The situation in respect of men was similar, in the sense that the group having completed only basic or primary studies was the largest. In the case of both sexes there were two people who had undergone university-level studies or training.

Graph 3 shows totals by level of education, age group and sex. It can be observed that the overall level of education and training was low. 
Figure 3. Study Population: Educational Levels by Age and Sex.

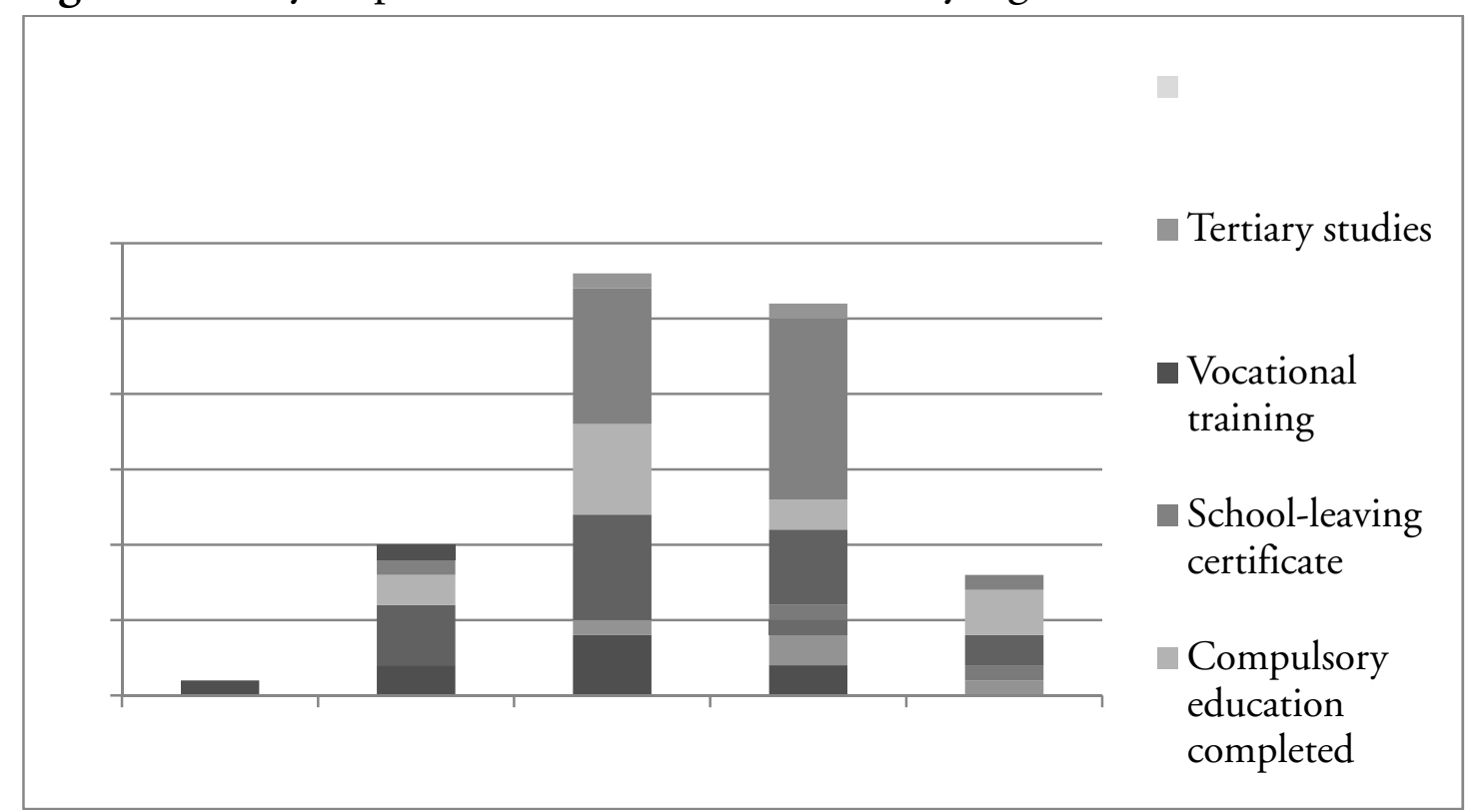

Source: Own elaboration.

In respect of place of birth or of origin of the individuals taking the greatest part in the study (79), this was very varied. However, somewhat more than half (46) were from Ponferrada. After these came a range of smaller groups made up of:

- Immigrants from outside the European Union, principally from Latin America, (9), coming from Bolivia, Ecuador, Argentina and the Dominican Republic.

- There were other immigrants from Portugal (2) and Morocco (2).

- Another group were people from other districts elsewhere in the Province of Leon (8).

- People from provinces in other parts of Spain (12).

With regard to the risk groups into which the various individuals fell, these were also varied in size. Thus, for example, there were disabled people (13), ethnic minorities, principally Gypsies (5), immigrants (11), former drug addicts (1). The remainder, a large number, came under the heading "Others". Analysis of the data showed that this grouping was composed for the most part of women. These, regardless of their age and marital status, had some further added feature. Thus, they were mostly separated or divorced women, victims of domestic violence; separated or divorced women entering the labour market; or single women with family responsibilities (involving parents or children).

To sum up, the profile of the population of participants was fundamentally one of middle-aged individuals, between 30 and 50 years old, having only a basic education or a low level of training, among whom the proportion of women was high, these primarily being separated or divorced. 
Analysis of the information gathered showed that, despite a good predisposition towards working among those surveyed, there was a whole series of factors that made it impossible for them to find employment. Among these was one affecting nearly half of those questioned, who stated that they did not have the work experience required for a job. A similar proportion declared that they did not have the educational level or training demanded. In both cases those affected were generally people who were seeking their first regular job with a contract and contributions to the Social Security system. They were for the most part women, regardless of their age. Moreover, it should be kept in mind that the set of people involved were usually looking for employment that required few qualifications and little training. Yet, however little was being asked for, they were not able to provide it, unless they had been undergoing training for some very specific type of work.

Another argument put forward in relation to the previous claim was that they had never worked or were not accustomed to working. This is to be understood, of course, as a working day subject to a strict timetable, lasting for a considerable time, and the like. This also is an obstacle to finding work, or rather, more specifically, to coming to terms with the world of work. A similar sized group felt that what prevented them from finding employment were their personal problems. In the majority of cases this referred to their family situation. Fundamentally, it was a question of having children to look after or caring for elderly people.

A smaller group among those surveyed, around a quarter, felt that what prevented them from finding work was a lack of the information and guidance needed to seek out a job. This group was generally made up of the disabled, principally those who had a disability of recent origin who needed to change their activity if they wanted to continue working. They were required to confront a new social and work situation, both in respect of the way of seeking employment and with regard to the type of work they could do.

Other factors constituting an obstacle to finding work that were also mentioned included the existence of social and workplace discrimination, this being cited generally by immigrants or women. It should be stressed that this view was not widely put forward by ethnic minorities, as might have been expected. There were also comments on the lines that business owners only want to exploit workers or that it is not worth working for the amount of pay that is on offer. To a lesser degree, there were arguments of the kind that if somebody gets a job, it is because of pulling strings. 


\section{Psychological and Social Characteristics and Attitudes towards Work}

As it has been pointed out in other place ${ }^{14}$, the people in the at-risk groups studied generally gave a positive image of themselves when asked about their qualities and attitudes towards work, even though they recognized that they were faced by a series of obstacles, lacks or other factors that made it impossible for them to get work. Thus, they considered themselves to be reliable and responsible in carrying out their commitments; they were ready and willing to work, and in general felt that they fulfilled the conditions for being a "good worker". Some stressed they were punctual, or good with their hands.

The following list of comments gathered during field work gives a sample of the values, attitudes and social and work priorities of some of the individuals who participated in the study. They can be seen to have similar characteristics to those typical of the working population that does not fall within any at-risk grouping:

\section{SELF-ESTEEM:}

- In my job I was recognized as a professional (HCP).

- In the places where I've been, people have been delighted with me (AVL).

\section{SACRIFICE:}

- I've worked a lot of hours for very little money (TSM).

\section{IMPORTANCE OF THE FAMILY:}

- My parents support me in everything (PFG).

- For me, my children are the most important thing (APF).

- You have to maintain your family (IPG).

\section{SPIRIT OF SACRIFICE (Abnegation)}

- I've never complained about hard work (AGM).

- Need makes you take whatever is on offer (NLM).

\section{CRITICISMS OF THE WORLD OF WORK:}

- They normally hire young girls (PLL).

- They just want a beautiful girl measuring 36-24-36 (CCC).

- However many qualifications I have, they are no use unless I find work (PPM).

- Less pay than I was hoping for (FGB).

- There's no such thing as continuity of employment (APB).

- Just where do they really give men and women equal pay? (AGM).

- I've worked a lot of hours for very little money (TSM).

- If a man puts in his C.V. that he's got a six-year-old child, it won't be a problem for him (MJLC).

- I've got experience, but I have no way of proving it (NLM).

14 Fernández, O. "La inserción sociolaboral de colectivos de riesgo". Actas VII Congreso Internacional de la Sociedad Española de Antropología Aplicada. (Santander, 2006). 


\section{FLEXIBILITY (Availability):}

- I'm an open person; I like to improvise; I'm as happy with the elderly as with small children (CVP).

\section{SOLIDARITY AND ASSISTANCE:}

- They've helped me a lot since I got separated (FGB).

- I very much like helping the elderly (AAA).

\section{ABUSE:}

- I've been an abused woman since I was sixteen (AFM).

- They've helped me a lot since I got separated (FGB).

\section{PHILOSOPHY OF LIFE (Way of looking at things):}

- I've looked for the meaning of life, but I haven't found it yet (AC).

- The world doesn't belong to any one person, it belongs to everyone (CPL).

- I'm being me; I like the person I'm turning out to be (CVP).

- Working is a way of being useful to society and it helps me to build relationships and realize my potential (PPM).

- I'm well aware of what the word Gypsy means and implies (CB-AJ).

- Work is only one part of my life (APB).

\section{WISHES:}

- I'd like to do what I'm best at doing (JRJR).

- Education is something I like; being able to pass on knowledge, that's an idea I find interesting $(\mathrm{CAF})$.

\section{OPINIONS:}

- As for me, if someone does me harm I forget them (AVT).

- Nowadays some things are not what they used to be; people change (CB-AJ).

- My friends are in the same situation (EM).

- Gypsy culture is never lost (JRJR).

- I hate unfairness; if somebody isn't right, I won't say they are (AVT).

\section{REJECTION:}

- People just don't accept you (PFG-I-).

- Since I'm a foreigner, I can't get work (LE).

- Business owners expect more out of us foreigners (DL).

- There are lots of handouts for foreigners, lots for the handicapped, but us single mothers need help too (RSG).

- I follow the rules, just like any Spaniard would (CPL).

\section{MISTRUST:}

- There's still a disliking for Gypsies (CB-AJ).

- If the first thing they look at is your race, that's wrong (CB-AJ). 


\section{DESIRE FOR IMPROVEMENT:}

- I've tried to learn everything I could (ROF).

- You have to be the best at what you do (AFM).

\section{INSECURITY:}

- I was afraid I'd look silly in a job I wasn't familiar with (JAB).

- I had giddy spells because of ear trouble and they wouldn't let me in, but what could I do? (IC).

\section{PREOCCUPATIONS:}

- Health is the number one thing (POG).

\section{DYNAMISM:}

- I don't like staying at home; I'd prefer to be out and about (CTD).

\section{Analysis and Assessment of the Data Obtained}

Generally, positive attitudes to work may be observed in the information gathered. That is to say, there is a relatively good motivation for seeking employment, even if it is in given sectors that normally require limited qualifications. In this way, the average "index of placeability", understood as the relationship between the personal and occupational profile and the posts to which people aspire, and what businesses usually demand for such posts, lies in general terms in bands which can be seen as normal if compared with those of groups that are not at risk of social or work exclusion, noted in some of the references listed at the end. This normal index arises from an overall analysis of the data, since if they are considered in closer detail, it would have to be adjusted downwards, as will be seen below.

This placeability index covered aspects mentioned above. These included the value attributed to employment and unemployment; availability for work; the personal and professional self-image; the style of search for employment; occupational maturity; skills demonstrated in the search for employment; social and family support; and the need for insertion. Although this evaluation was performed for each of the individuals who participated, here the results of an overview for each of the items will be given.

a) In respect of the value and worth set on work, although work was not considered the most important thing in life, since others such as health and the family were soon mentioned, it was felt that work is a means to self-fulfilment. In this sense, there would be other reasons making it important and necessary to work, besides making one's living. The majority also believed that it is better to live by one's own work than to be dependent on one's family or on society, whether through handouts or benefits. However, on this point not all informants were unanimous. 
b) With regard to the values attributed to unemployment, the majority felt that in varying personal situations, its causes are fundamentally to be sought in the peculiarities of each person. That is, it was recognized that among the reasons for not finding work would be lack of experience, lack of training, personal character, or even not knowing where or how to seek it. Thus, it was understood that the situation of unemployment in which individuals find themselves does not depend exclusively on the shortage of offers of work, but upon other factors, among which personal capacities are one of the most crucial. Likewise, although it was also accepted that the fact of having influential friends or being able to pull strings might make it easier to get employment, this was not a factor considered to be of any great weight, and it was seen as being in the area of intangibles, of luck, and hence uncontrollable.

c) With respect to availability for work, individuals generally indicated they were ready and willing to do any sort of work, within the framework of preferences relating always to limited qualifications. People were even prepared to lower their aspirations as long as there was some sort of a job, or even to work in marginal or illegal situations, or in the black economy. However, there was no such availability for employment if it required a change of place of residence, away from Ponferrada and its surroundings, or implied working to a strange or difficult timetable.

d) With regard to personal and professional self-image, individuals consider themselves sufficiently prepared to carry out the jobs to which they wish to gain access. It has already been mentioned that these are generally low-grade employment. People even think they would be good at these jobs and that their image and personal appearance is ideal for such employment. Hence, they think they would have no trouble at all in doing the work. Moreover, there is always an underlying belief in all individuals that they are good workers in their speciality.

e) As for the style of search for employment, it is mostly recognized that efforts put into seeking work are not very assiduous. There is no continuous dedication to this, as something for which time is set aside every day. In most cases, it is even true that very few hours a week are spent on looking for work. Whether it is through their being tired with the process, or because some people have been searching for work for a long time, search activity is mostly sporadic or occasional, and when it does take place it is because of a suggestion, imposition, or recommendation from somebody else than those concerned. This is frequently because they are carrying out a series of activities or doing informal work by the hour and it is only when they are free and have time that they set out to look for work.

f) In accord with this viewpoint, the occupational maturity demonstrated is not great. This means that they do not think it necessary to train or to be recycled in the employment to which they aspire, or even to continue training in the job that they might be doing. Whether this is because the work they would like to have is low grade, or because what they are seeking is just a job of any sort, training is 
viewed as something that may help in finding employment, but that is not always such. This is the explanation for the different and contradictory opinions expressed about training courses.

g) With respect to the skills shown in seeking employment, those individuals who have attended training courses, or who receive counselling from the Social Action service, do have some idea, at least in theory, of what constitutes an employment interview, of how to behave in such situations or of how to draw up their curriculum vitae. However, the limited work experience of some, or the fact that they have never attended training courses, leads them not to have any clear idea of how to present themselves when seeking work, what to do or say in an interview, how to get through a situation of that kind, or how to conduct a planned and orderly search for employment. This is despite the fact that they generally mention that they have received assistance in these matters from social services.

h) With reference to social and family support, most individuals recognize that they receive aid and encouragement from family members and friends in respect of undergoing training and of seeking work, and even that it is these people who inform them about job offers. However, in the same way, many people state that it is their own family situation that prevents them from seeking employment or indeed from taking on work offered.

i) As for the need for social and work insertion of the individuals surveyed, they are generally considerable, as apart from having to work to maintain themselves, most have family responsibilities. Paradoxically, as mentioned above, these are sometimes what prevents them from working. However, they do not describe their situation as desperate, since in most cases social welfare allowances or casual work by the hour provide some solution to the problem.

\section{What Employers Say ${ }^{15}$}

In general terms, to sum up the information provided by business people, employers and institutions, these all said that they set no different value on workers because of their belonging to one or another social group. What they stated they valued is a hard worker, who carries out the work assigned in an acceptable way. What they also said they take into account is that there are numbers of individuals who may have a range of personal, family or social difficulties that may affect the way they do their work. However, according to the views expressed by the majority

15 Collaboration and responses were received from small- and medium-sized businesses, in sectors such as electrical installations, the automotive trade, bakeries, food production, the meat trade, cleaning, trade unions and the social action service. The degree of representativeness cannot be seen as very high, since the level of co-operation was low. 
of employers, this can equally well happen to people not belonging to any of the groups being considered.

Even so, they did mention groups that may face rejection, top of the list being drug addicts and former drug addicts. These were followed by ethnic minorities, particularly Gypsies, and also by immigrants. The fundamental reason they gave was the lack of confidence they could have in such people for doing a job. This was related to the statement that what is most highly valued in a worker is honesty. Honesty was seen as the first step to taking responsibility, and responsibility as something that permits workers to be trusted. Another reason related to the poor image some individuals can present.

On this point, it was also pointed out that some of the groups under study prioritize false needs, since they see work as just an obligation, which shows their lack of maturity and, once again, of responsibility. In the same fashion, with regard to the bad image previously mentioned, reference was also made to their being too "laid back", as they are lazy and casual and have a number of problems they ought to solve first.

Similarly, mention was made of the problems that may be faced by the disabled, as not all businesses are physically equipped to allow them to work and thus are technically unprepared to incorporate them. However, this was the group achieving most acceptance from those business people who had a handicapped person working in their enterprise.

The reasons given by employers for incorporating one or another of the groups under study into their staff were fundamentally connected to the assistance available, whether as tax relief, subsidies, or in other forms. There was very little altruism, and even a mention of the possibility of requiring a commitment to achieve a good image, on the part either of the workers or of the institutions that are responsible for them or sponsor them.

Moreover, they considered it evident that it is workers themselves, whatever group they may belong to, if any, who must make a commitment to, and take responsibility for, their work, show that they cause no problems and fulfil their duties like everybody else.

It is significant that the majority of the employers who agreed to collaborate in this study already had individuals from one or another of the groups under consideration working in their businesses. The level of satisfaction with them was high, although they have had to go through a series of adjustments in order to reach this degree of acceptance and normality. This refers to the problems that there have been and which they consider affect these groups, the first of which is the lack of a habit of working: some of them are just not accustomed to work. From this there can arise a problem of a lack of work experience in different sectors or of specific training for these sectors. An additional difficulty, noted as a secondary cause, are 
the various personal or social problems these individuals may have. It is even worse if because of these situations they do not know how to fit into society.

Employers as a group also referred to a number of deficiencies in these groupings with respect to knowledge, skills, capabilities and abilities, social and work-related, considered vital or seen as desirable in the various types of job. In this respect, there are various levels of requirements. In general employers required people to have the necessary training for the work to which they wanted to gain access. This may seem self-evident, but at the lowest levels of employment, even casual work, it does at least require an ability to read and write. This to some degree demolishes the argument put forward by many individuals that, for example, to be a cleaner, you need to know how to clean, and that is all. The view of employers was rather more that to be a cleaner one also had to be able to read what it says on the bottle of cleaning fluid and understand what it means, so as to use it appropriately and not to become involved in personal accidents or damage objects.

\section{Conclusions, Tools and Strategies for Consideration}

The majority of the individuals in the various vulnerable groups participating in this study suffered from a number of educational, work-related, attitudinal and social deficiencies that prevented them from reaching an adequate condition to get access to a job. Their chances of gaining employment were further reduced because in addition very few had even the minimum specific vocational training required by most jobs available. Some of these individuals, aware of their educational and vocational deficiencies, attempted to get casual employment which they supposed would require little training or professionalization. However, as shown by the evidence, this is an error, as even for casual work one has to be trained.

It is thus a question of designing training and incorporation into the world of work on the basis of filling these gaps in capacity, in a way that must be flexible, broad-ranging and participation-based. The challenge in this idea is that, starting from the capabilities of each person and their efforts, there should be a two-way commitment. On the one side, it would be from individuals through projects or routes for inclusion that would be personal and guided. On the other, it would be from bodies, whether from the administration supporting them, or from the enterprises or institutions giving them work and receiving assistance for offering a contract to the individual concerned.

Such personal inclusion routes, as arrangements involving both financial assistance measures and training or orientation actions, including social skills, should have a clear and precise sequence, with well defined objectives for differing phases (welcome, pre-training, training, work experience, and so forth). Their methodology and design should be flexible, so as to leave room for a diversity of require- 
ments, in which getting a job should not be the end of the route, but rather the normal way of beginning social and work integration. They should include a possibility of direct access to employment, incorporate market surveys, and, in brief, act as an integrating strategy that will supply all the missing capacities of groups at risk of social exclusion.

Furthermore, it must be kept in mind that the current labour market is strongly governed by supply and demand and highly competitive. The most underprivileged groups are most likely to generate enclaves of exclusion from this market. This limits the extent to which a number of groups can gain access with equality of opportunities to a decent and properly paid job. Hence mechanisms for intermediation must be created, whose principal task is to offer employers and employees the minimum conditions to bring these two groups together. In the face of an attitude that may be termed centrifugal on the part of the two groups, which raise their requirements and have little flexibility in their demands, there should be a centripetal force from labour intermediaries who should seek a balance between those parties involved.

To conclude, from the analysis of the data, a series of tools and strategies for consideration emerge, shown in condensed form in the following general outline of the study.

Oscar Fernandez is lecturer in Social Anthropology at the University of León, in Spain, oscar.fernandez@unileon.se. 
Figure 4. General Outline of the Study.

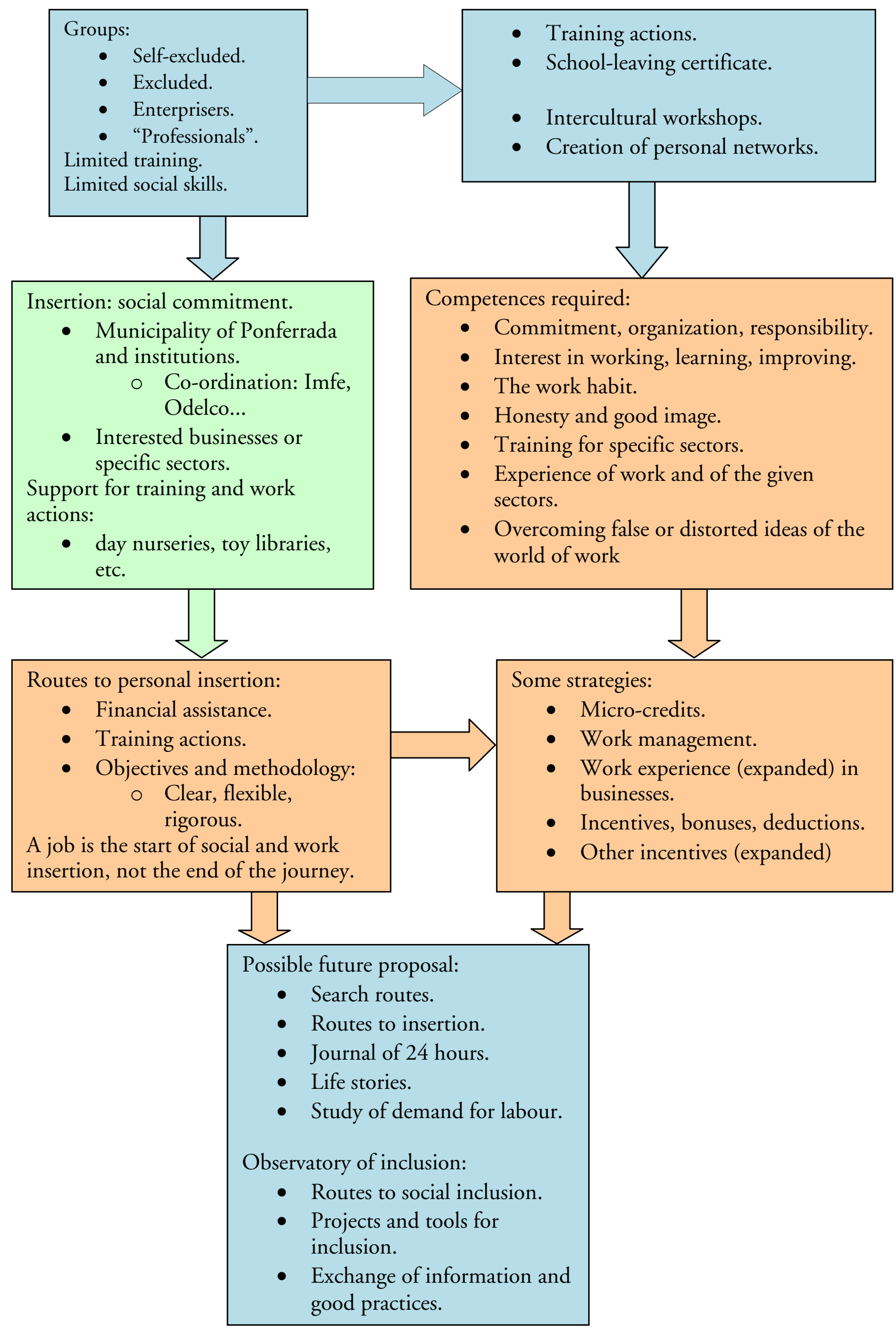




\section{References}

Atkinson, A. B., Cantillon, B., Marlier, E. and Nolan, B. Taking forward the EU social inclusion process. (Luxembourg, 2005),

http://www.ceps.lu/eu2005_lu/inclusion/report/final_report.pdf.

Barnes, M. Social Exclusion in Great Britain. An Empirical Investigation and Compari-son with the EU. (Aldershot, 2005).

Barnes, M., Heady, C., Middleton, S., Millar, J., Papadopoulos, F., Room, G., and Tsakloglou, P. Poverty and Social Exclusion in Europe. (Cheltenham, 2002).

Böhnke, P. Am Rande der Gesellschaft: Risiken sozialer Ausgrenzung. (Opladen, 2006).

Burchardt, T., Le Grand, J. and Piachaud, D. "Degrees of exclusion: developing a dynamic, multidimensional measure", in Hills, J. Le Grand, J. and Piachaud, D. (eds.), Under-standing Social Exclusion. (Oxford, 2002).

Castel, R., Las metamorfosis de la cuestión social. (Buenos Aires, 1997).

Colectivo IOÉ, "Barómetro Social de España: nuevos indicadores sobre la evolución del país" en Papeles de relaciones ecosociales y cambio global, CIPFUHEM, 101 (2008), pp. 165-185.

Colectivo IOÉ, "Inmigrantes extranjeros en España ¿Reconfigurando la sociedad?”, Panorama Social, (2005), 1, pp. 32-47.

Fernández, O. "La inserción sociolaboral de colectivos de riesgo". Actas VII Congreso Internacional de la Sociedad Española de Antropología Aplicada. (Santander, 2006).

Fitoussi, J. and P. Rosanvallon, La nueva era de las desigualdades, (ed.) Manantial, (Buenos Aires, 1998).

Gil, M.A., "Empresas de inserción: contexto, orígenes y situación". Herramientas, (2003) 69, pp. 34-41.

Gordon, D., et al., Poverty and Social Exclusion in Britain. (York, 2000).

Littlewood, P. and Herkommer, S. "Identifying social exclusion: some problems of meaning", in Littlewood, P. (ed.), Social Exclusion in Europe: Problems and Paradigms. (Aldershot, 1999), pp. 1-22.

Silver, Hil "The process of social exclusion: the dynamics of an evolving concept", Chronic Poverty Research Centre, Working Paper, 95. (London, 2007). 